Portland State University

PDXScholar

\title{
Stream Sedimentation Patterns in an Urban Beaver System: Fanno Creek, Oregon
}

Alexandra Joan Santora
Portland State University

Follow this and additional works at: https://pdxscholar.library.pdx.edu/geog_masterpapers

Part of the Physical and Environmental Geography Commons

Let us know how access to this document benefits you.

\section{Recommended Citation}

Santora, Alexandra Joan, "Stream Sedimentation Patterns in an Urban Beaver System: Fanno Creek, Oregon" (2017). Geography Masters Research Papers. 21.

https://pdxscholar.library.pdx.edu/geog_masterpapers/21

10.15760/geogmaster.20

This Paper is brought to you for free and open access. It has been accepted for inclusion in Geography Masters Research Papers by an authorized administrator of PDXScholar. Please contact us if we can make this document more accessible: pdxscholar@pdx.edu. 
Stream Sedimentation Patterns in an Urban Beaver System:

Fanno Creek, Oregon

by

Alexandra Joan Santora

A research paper submitted for partial fulfillment of the requirements of the degree of

Master of Science

In

Geography

Approved by:

Advisor

Member

Member

Department Chair

Portland State University

2017 


\begin{abstract}
$\underline{\text { Abstract }}$
Beaver activities can cause drastic changes to hydrogeomorphic processes by impounding waterways through the construction of dams, trapping sediments and reducing the downstream sediment load. The presence of beaver is increasing in urban areas. Urban streams exhibit hydrogeomorphic processes distinct from natural systems because of changes in land cover that alter hydrology. This case study was developed as part of an effort to understand the sedimentation patterns of a beaver impounded urban stream in Beaverton, Oregon. Twelve sediment samples were collected and processed for organic matter content and particle size and sediment depths were calculated using GIS software from data collected through bathymetric and depth-to-resistance surveys. Spatial variability of and correlations between sample composition and depth were examined through visual analysis and descriptive statistics for in-channel/floodplain and upstream/downstream comparisons. Sediment depth and organic matter were found to be highest immediately upstream of the dams and in the floodplain pond, which exhibited decreasing depth with distance downstream. Floodplain organic matter and particle sizes did not display distinct spatial patterns. Moderate correlations were identified between composition and sediment depth for both floodplain and in-channel samples. Opposite correlations were identified between organic matter and particle size for floodplain versus in-channel samples. These results provide an understanding of baseline conditions for the study area under beaver impoundment. Future research should work towards collecting more robust datasets at a variety of sites and spatial scales to understand the full spectrum of the influence of beaver in urban basins.
\end{abstract}


Introduction $\quad 1$

Beavers and Geomorphic Change $\quad 4$

$\begin{array}{ll}\text { Methods } & 8\end{array}$

$\begin{array}{lr}\text { Study Area } & 8\end{array}$

Sample Collection $\quad 13$

$\begin{array}{ll}\text { Sample Processing } & 14\end{array}$

$\begin{array}{ll}\text { Depth Surveys } & 16\end{array}$

Sediment Depth 17

$\begin{array}{ll}\text { Data Analysis } & 17\end{array}$

$\begin{array}{ll}\text { Results } & 19\end{array}$

Sample Composition $\quad 19$

$\begin{array}{ll}\text { Sediment Depth } & 19\end{array}$

$\begin{array}{ll}\text { Data Analysis } & 21\end{array}$

$\begin{array}{ll}\text { Discussion } & 28\end{array}$

Floodplain Sediments $\quad 28$

$\begin{array}{ll}\text { In-Channel Sediments } & 30\end{array}$

Limitations of this Study $\quad 34$

Conclusion $\quad 36$

References $\quad 37$

$\begin{array}{ll}\text { Appendix } & 41\end{array}$ 
Figure 1. Map of Fanno Creek and Tualatin River

Basins with study area

Figure 2. Map of study area. $\quad 10$

Figure 3. Image: Dam $1 \quad 12$

Figure 4. Image: Dam 2 12

Figure 5. Image: Dam $3 \quad 13$

Figure 6. Equations used to calculate sediment 16 particle sizes.

Figure 7. Diagram defining bathymetric and depth-to-resistance. 17

Figure 8. Map representing sediment depths. 21

Figure 9. Map showing the spatial distribution and 23 boxplot showing distribution of values of organic matter.

Figure 10. Boxplot and graphic of organic matter percentages 24 upstream and downstream of the dams.

Figure 11. Percent sand, silt, and clay for individual samples. 25

Figure 12. Correlation matrices for floodplain and in-channel 26 sediment samples.

Figure 13. Correlation matrices for floodplain and in-channel 28 sediment composition 
Table 1. Sediment Sample Identification 14 and Location Table

Table 2. Results of Sample Processing 19

Table 3. Sediment Depths Calculated from 20 Interpolated Survey Surfaces

Table 4. Mean Percentage of Particle Size by Location 


\section{$\underline{\text { Introduction }}$}

Sedimentation causes degradation in freshwater systems, such that the US EPA has identified sediments as a pollutant of concern (1992). Suspended sediments increase turbid conditions, reducing light penetration and disrupting photosynthetic and respiration processes, as well as foraging and predation dynamics (Lemly 1982). The deposition of fine sediments, sands, silts, and clays (diameter $<2 \mathrm{~mm}$ ), in a stream can change channel substrate (Graham 1990), altering near- and subsurface physical and chemical processes and degrading ecosystem conditions (Wood and Armitage 1997).

Streams in urban systems generally develop degraded ecological, hydrologic, and geomorphic conditions, often referred to as "urban stream syndrome" (Walsh et al. 2005). Urban impervious surfaces create increases in discharge, erosion, incision, and pollutants, the creation of homogeneous channel structure, and changes to biotic communities. In areas dominated by fine-grained soils, urbanization results in increased fine sediments in streams, through both external sources and in-channel erosion.

Typically, the primary supply of sediment within an urban stream channel is the small fine grain suspended sediment transported from upstream (Pollock et al. 2014). The fine grain fraction readily absorbs nutrients and other pollutants, such as heavy metals and pesticides (Paul and Meyer 2001). Low concentrations of suspended sediments can increase the dissolved potential of even hydrophobic pollutants, which do not readily dissolve (Karickhoff et al. 1979). High concentrations of suspended sediments can restrict the amount of sunlight able to penetrate the water column reducing the growth of algae, aquatic vegetation, increasing temperature, and can be detrimental to species survival, inhibiting predation, foraging, and spawning (Wood and Armitage 
1997).

In addition to minerogenic fine sediments, streams transport small organic matter particulates from decomposing plants and animals. Organic matter provides a number of essential functions in natural systems. It increases the infiltration and water hold capacity of soils, which improves soil structure, stabilizing soils and reducing erosion. Organic matter also acts as an important supply of nutrients for bacteria, microinvertebrates, and plants. Steady supply of organic matter overtime improves the longevity of the system by fortifying food supply up the ecological pyramid. However, increased organic matter can deplete the amount of dissolved oxygen (DO) in the stream, which can negatively affect aquatic life. Urbanized basins have been found to contain low DO and less demand for DO, an indication of the decreased ability of urban streams to sustain life (Wang et al. 2003). The amount of organic matter contained in a stream can also enhance the conditions associated with high volumes of by fine sediments as discussed above.

Although fine sediments and particulates are primarily transported as suspended material, deposition occurs as a result of changes to stream hydrogeomorphology, including discharge, depth, time, and turbulence. Beaver alter a stream's ability to transport suspended particles by building dams across channels, slowing flow velocities, reducing discharge, and creating a physical barrier (Devito and Dillon 1993). In contrast to urban systems, beaver engineer ecosystems that are capable of reducing erosion and encouraging deposition, increasing channel complexity by altering channel geometry and substrate, sequestering and transforming nutrients and other pollutants, and increasing species diversity (Burchsted et al. 2010, Pollock et al. 2014). Urban ecosystems with the space to accommodate beaver may also be able to benefit from the ecosystem services 
generated by beaver activity.

Recent management of sediments in urban streams is beginning to capture the attention of stream restoration researchers and managers from a new perspective. Pollock et al. (2014) developed an ecogeomorphic model for incised streams. This model incorporates the principles of beaver dam hydrogeomorphology to reverse channel incision by encouraging sediment deposition in the channel. This could be used as a model for mitigating the multiple damaging effects of urbanization on streams.

The purpose of this research was to understand the deposition of sediments as a component of the system response to beaver activity in Fanno Creek by examining the characteristics of sediment deposited in an urban stream reach containing multiple beaver dams. This research sought to determine whether if deposited organic matter (OM) and the sediment particle sizes varied spatially. Additionally, this research tried to determine if relationships exist between organic matter content and the depth of the deposited sediments, as well as between sediment composition and the depth of the deposited sediments.

Organic matter and particle sizes were analyzed separately to compare of inchannel samples and floodplain samples. Additionally, in-channel samples were assessed based on position within the dam system (upstream/downstream).

This research was conducted in the hope that the results identified in this study can assist land managers in achieving a baseline understanding of how beavers are influencing the characteristics of sediments in urban beaver systems and determine the steps needed to optimize the benefits and limit the risks of beaver in urban streams. 


\section{$\underline{\text { Beaver and Geomorphic Change }}$}

In natural environments, beaver influence the composition and complexity of a stream ecosystem (Paine 1969); as ecosystem engineers they modify the physical environment, spurring biogeochemical reactions and biotic and abiotic transformations (Jones et al. 1994). In urban environments, beaver populations are generally perceived as a nuisance species, responsible for inducing flooding and causing damage to private property and local infrastructure. Yet recent research and stream restoration efforts have being bridging the gap between human built and natural systems by focusing on the influence of beaver dams and beaver dam analogues (BDAs) for improving degraded stream conditions (Pollock et al. 2014).

Human built environments put pressure on existing natural systems. Humans tend to inhabit landscapes also preferred by beaver: low gradient areas with unconfined valley streams (Pollock et al. 2015), developing floodplains adjacent to waterbodies for agriculture and settlement. A positive feedback loop is created as the increase in impervious surfaces alters basin hydrology, increasing in discharge, erosion, and pollutants, and reducing channel complexity and aquatic diversity (Paul and Meyer 2001). In urban systems where beaver are present, the effects of urbanization may be dampened.

Beaver may be capable of mitigating the processes that degrade urban streams. Through beaver intervention, stream corridors experience a shifting evolution of freeflowing, ponded, and upland habitats (Burchsted et al. 2010). This evolution is a result of beaver directly altering channel hydrology by impounding streams, creating a resistance to flow that reduces peak discharges (Pollock et. al 2003), which is a common problem in 
urban streams. Well established beaver dams are less prone to being breached by high volume, high velocity flows. Dams in a series diminish the timing and magnitude of discharge by creating a multiple step-pool effect through the stream's longitudinal profile (White 1990, Burchsted et al. 2010).

This reduction of discharge volume and velocity has important implications for urban channels that are subject to deepening and widening by erosion. By damping peak discharges, beaver dams reduce the erosive power of a stream (Pollock et al. 2003). However, attenuating peak discharge is not enough to reverse channel incision. In order for aggradation to occur, deposition must be encouraged through reconnection to the floodplain and riparian areas (Pollock et. al 2014). This reconnection increases roughness and induces overbank deposition on the floodplain. Deposition will also occur behind a dam and, in both locations, sediment deposition is often heterogeneous, consisting of a mix of sediment sizes, debris, and organic matter (Grunell 1998, Sullivan et. al 1979).

Sediment deposition in the channel increases the geomorphic complexity of the stream (Keller and Swanson 1979). In urban streams with relatively little geometric variability, this can create channel bars and riffle-pool sequences. Where vegetation establishes, resistance increases and the potential for erosion and re-incision decreases (Pollock et al. 2007). Channel complexity increases habitat for aquatic biota and can be used as an indicator of species richness (Violin et al. 2011). When a beaver dam is breached, stored sediments can be released adding to the complexity of the stream channel within and downstream of the dam system. The released highly mixed sediments cause deposited sediments to be more resistant to entrainment (Charlton 2008), 
stabilizing the channel.

Sediment mixing is beneficial beyond the in-channel erosion-aggradation processes. Sediment deposition on the floodplain provides rich organic material for vegetation and allows for biogeochemical processing to occur. The high productivity of saturated sediments with elevated organic matter content can create anoxic conditions, acting as a sink for nitrogen and carbon (Naiman et. al 1986 and 1988). Following denitrification, reduction of magnesium oxide, iron oxide, and sulfate can occur (Champ et al. 1979). These transformations can greatly influence aquatic communities. For example, iron oxides are less toxic to aquatic biota after reduction and this process can neutralize the $\mathrm{pH}$ of a stream (Gerhardt 1992), an important process for urban streams experiencing higher acidity.

The configuration of vegetation benefits from beaver-engineered ecosystems. Floodplain deposits create layers of rich organic material that can serve as a source of nutrients for plant growth and can provide habitat suitable to foster microinvertebrate consumption and bacterial transformations. Vegetation can also become established on in-channel bars as a result of aggregation encouraged by beaver dams' reduction of discharge. In addition to stabilizing the channel, vegetation can also directly moderates stream temperature by shading the stream channel. Beaver reconnect riparian vegetation to previously shallow sources by raising local water tables (O’Driscoll et al. 2010). This is especially important in areas where stream levels drop either because there is little to no precipitation during the warm summer months or in urban streams that experience lowered baseflows because of channel incision. Low level flows create "drought" conditions for disconnected riparian vegetation (Groffman et al. 2003). Healthy riparian 
vegetation contributes leaf litter to the channel and can increase the organic matter content in the stream, providing food for aquatic invertebrates and influencing biogeochemical processes.

Beavers create beneficial positive feedback loops in streams. In urban streams, this means a reduction of peak discharge, increased channel and floodplain complexity, water retention, biogeochemical processing, and trophic diversity. In urban areas, streams serve important functions as terrestrial and aquatic habitats, climate moderators, conveyance systems, and cultural and social landscapes (Walsh et al. 2005). With limited space but abundant problems, urban areas need to adjust policy to protect and restore natural resources, such as urban streams. As urbanization amplifies natural processes in detrimental ways, beaver can restore natural processes in beneficial ways; however, humans must learn to understand ecosystems as dynamic and accommodate for natural fluctuations (Burchsted et al. 2010). Perhaps most important is the understanding that humans must compromise to alleviate the problems imposed urban streams at the source (ie. by reducing impervious surfaces), instead of looking to mitigate the symptoms. 


\section{$\underline{\text { Methods }}$}

\section{Study Area}

Fanno Creek is a tributary in the Tualatin River Basin, near Portland, Oregon. Fanno Creek's total drainage area is $82.4 \mathrm{~km}^{2}$. The basin is dominated by fine sediments and organic matter (Keith et al. 2014). The mid-section of Fanno Creek within Greenway Park, Beaverton, Oregon was the site for this research (Figure 1). The reach lies 14.5 kilometers from the headwaters and 16.1 kilometers from the mouth and consists of approximately 0.3 kilometers (270 meters) of stream channel. This section of Fanno Creek is a low gradient stream channel dominated by silty soils with slow infiltration rates (Natural Resources Conservation Service 2012). The surrounding area is predominantly urban land cover, while the adjacent land is a public park. Throughout its extent Fanno Creek has been subject to incision and widening, typical of streams in urbanized basins. 


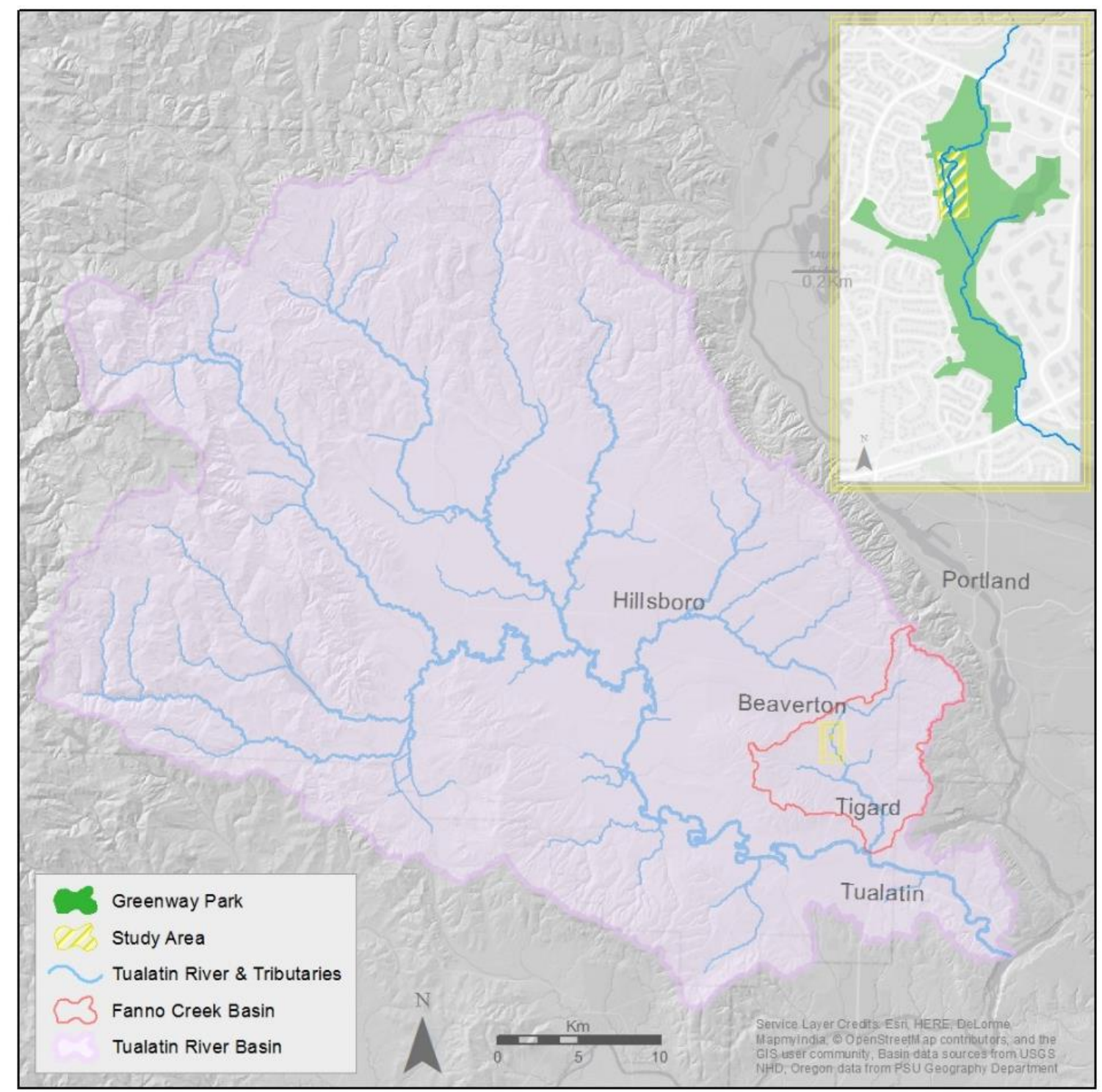

Figure 1. Map of study area in relation to the Fanno Creek and Tualatin River Basins

The study area consists of two channels: the main channel, constructed during the 2010-2011 channel improvement project (Clean Water Services (CWS) 2009), and the old channel, which served as the main channel prior to the channel improvement project and now serves as stormwater infrastructure (Figure 2). At the time of construction, the main channel was designed in a riffle and pool sequence, with bankfull depths varying between 1.5 and 2.1 meters, and dug to hardpan clay bank material. As part of the project, the old channel was disconnected from the stream network and filled with 
excavated material from the constructed channel to a depth of approximately 0.6 meters. The old channel maintains two stormwater outfall connections from the surrounding community (CSW 2009).

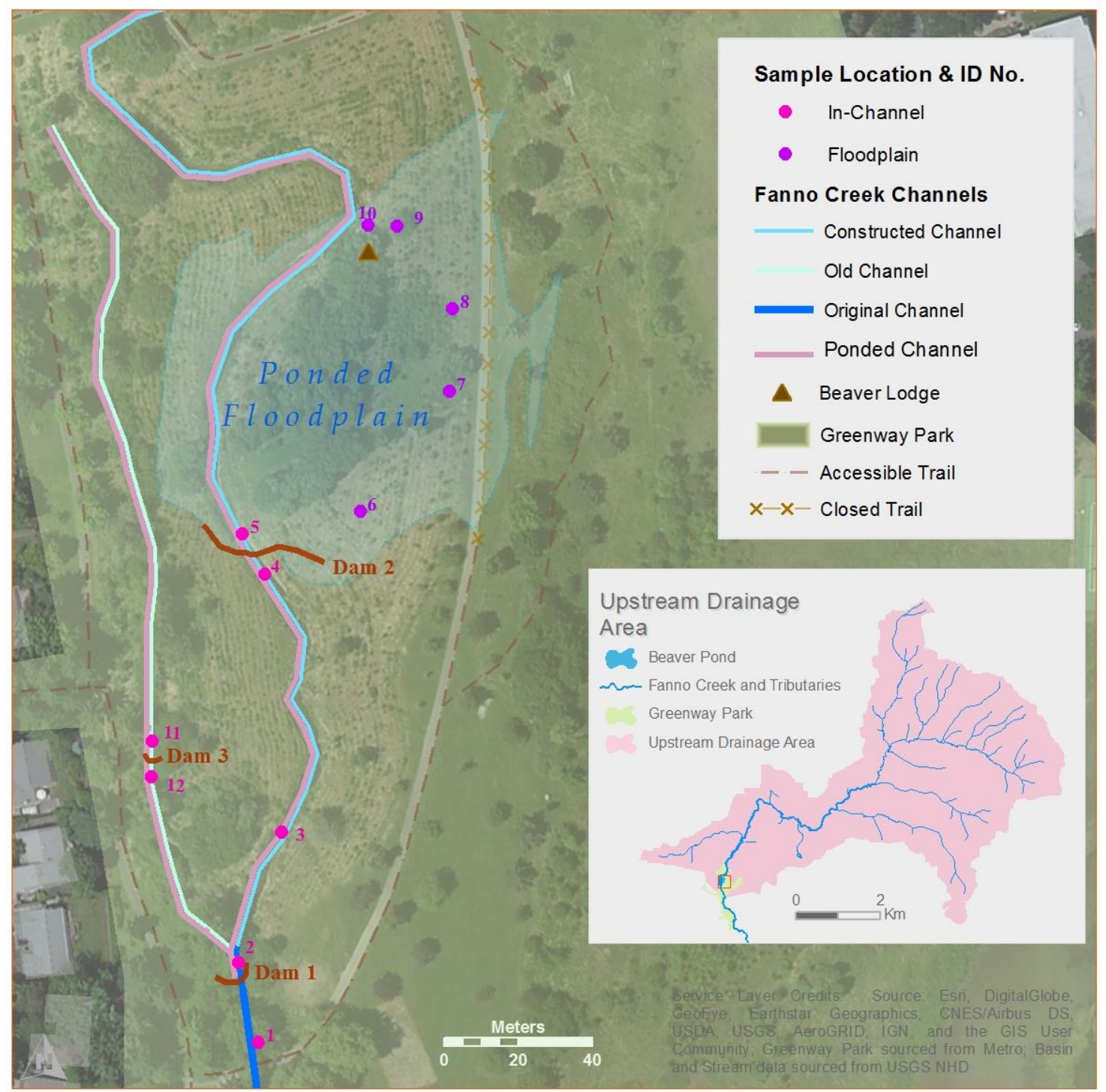

Figure 2. Map of study area under baseflow conditions, including dam and sample locations, channel descriptions, and inset map of the upstream drainage area.

There are three main beaver dams located within the study area (Figure 2). The dam locations were determined through field investigation in May 2016. Coordinates were taken across each dam using a Trimble Juno handheld GPS. Dam heights (upstream 
and downstream) and lengths were measured using a measuring tape and stadia rod and catalogued in the GPS database.

Dam 1 is located in the main channel, downstream of the confluence of the old and constructed channels. This portion of the channel was not modified during the channel improvement project. Dam 1 is a channel spanning obstruction, extending across the channel connecting floodplains on either side, without overbank extension (Figure 3). This dam is approximately 1.8 meters tall and 12.5 meters long. Channel ponding occurs upstream of Dam 1, extending to downstream of both Dam 2 and Dam 3. Channel avulsions are occurring at both right and left bank locations, allowing continuous flow.

Dam 2 is located in the constructed channel approximately 127 meters upstream of Dam 1. Dam 2 is of floodplain spanning construction, extending across the channel, with overbank extensions across right and left floodplains (Figure 4). Dam 2 is approximately 1.9 meters tall (within the channel) and was 37.2 meters long at time measurement. Floodplain and channel ponding occur upstream of Dam 2. This pond surface area fluctuates but is approximately $8,600 \mathrm{~m}^{2}$. Continuous flow is redirected over both left and right banks. Depending on water levels, right bank flow connects to both the main channel and the old channel.

Dam 3 is located in the old channel approximately 67 meters upstream of Dam 1. Dam 3 spans the channel, extending across the channel connecting floodplains on either side, without overbank extensions (Figure 5). Dam 3 is approximately 0.35 meters tall, 6.2 meters long, and exhibits overtopping continuous flow. 


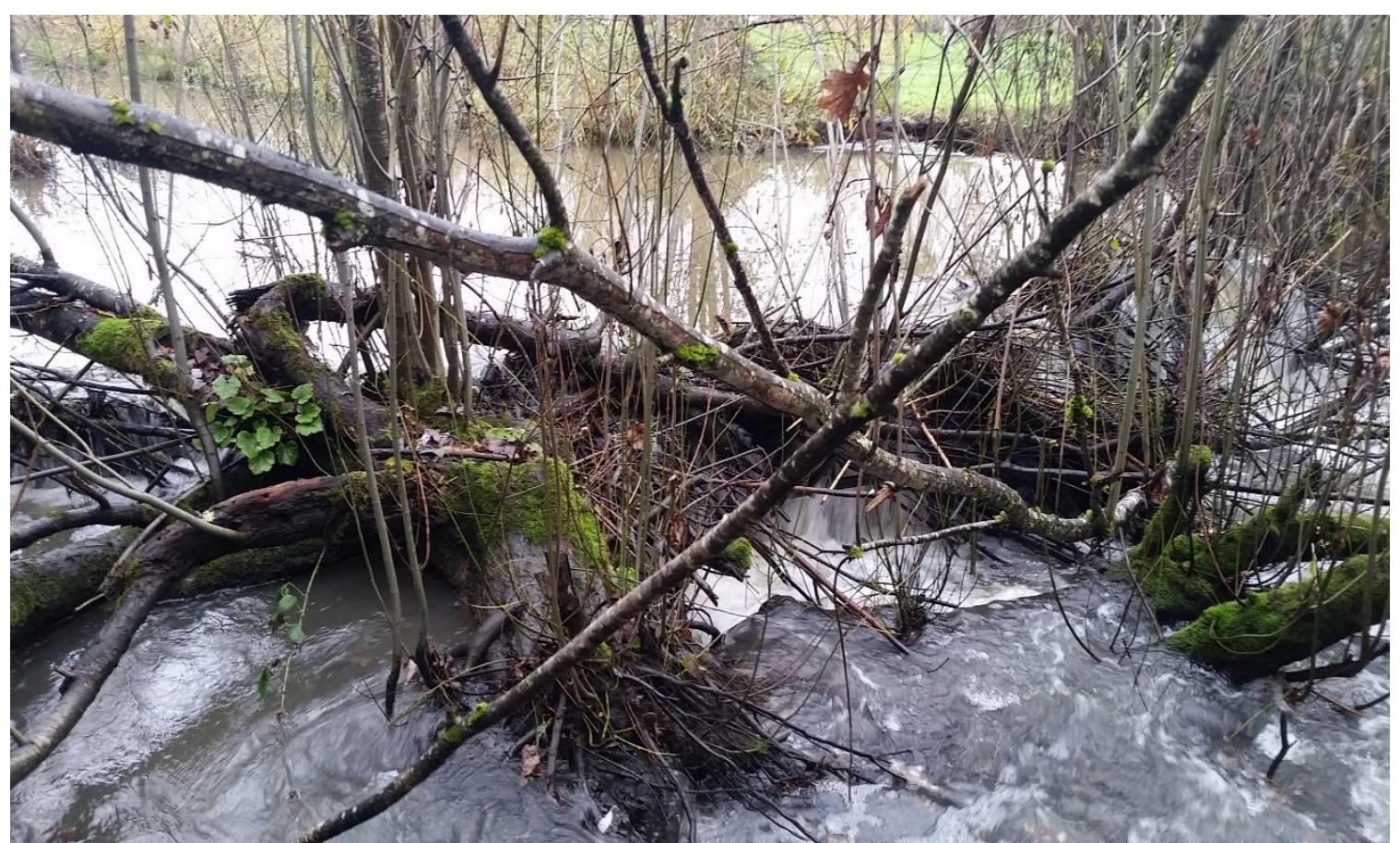

Figure 3. Dam 1 from (slightly) downstream right bank, oriented to upstream left bank.

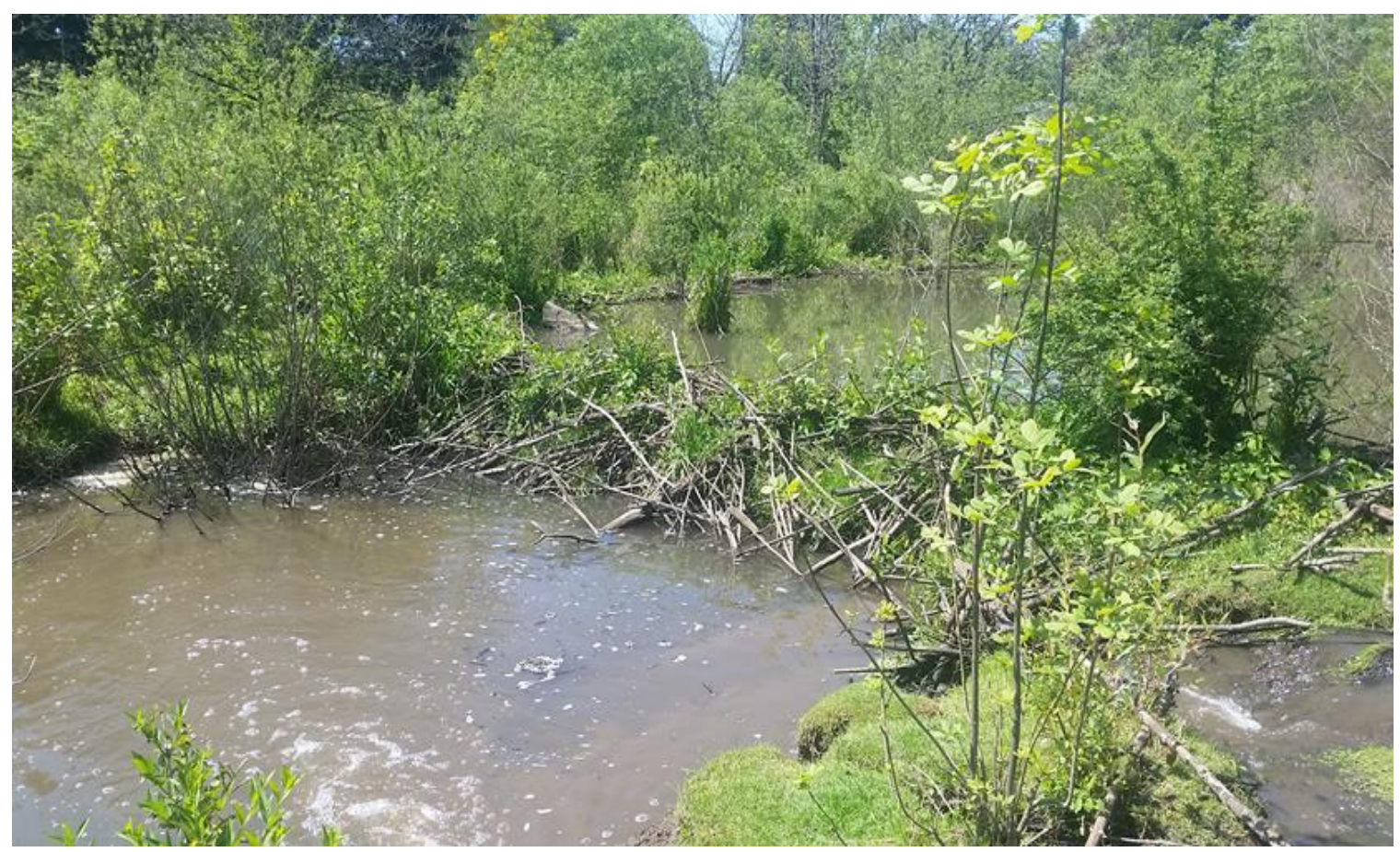

Figure 4. Dam 2 from left bank oriented to upstream right bank. 


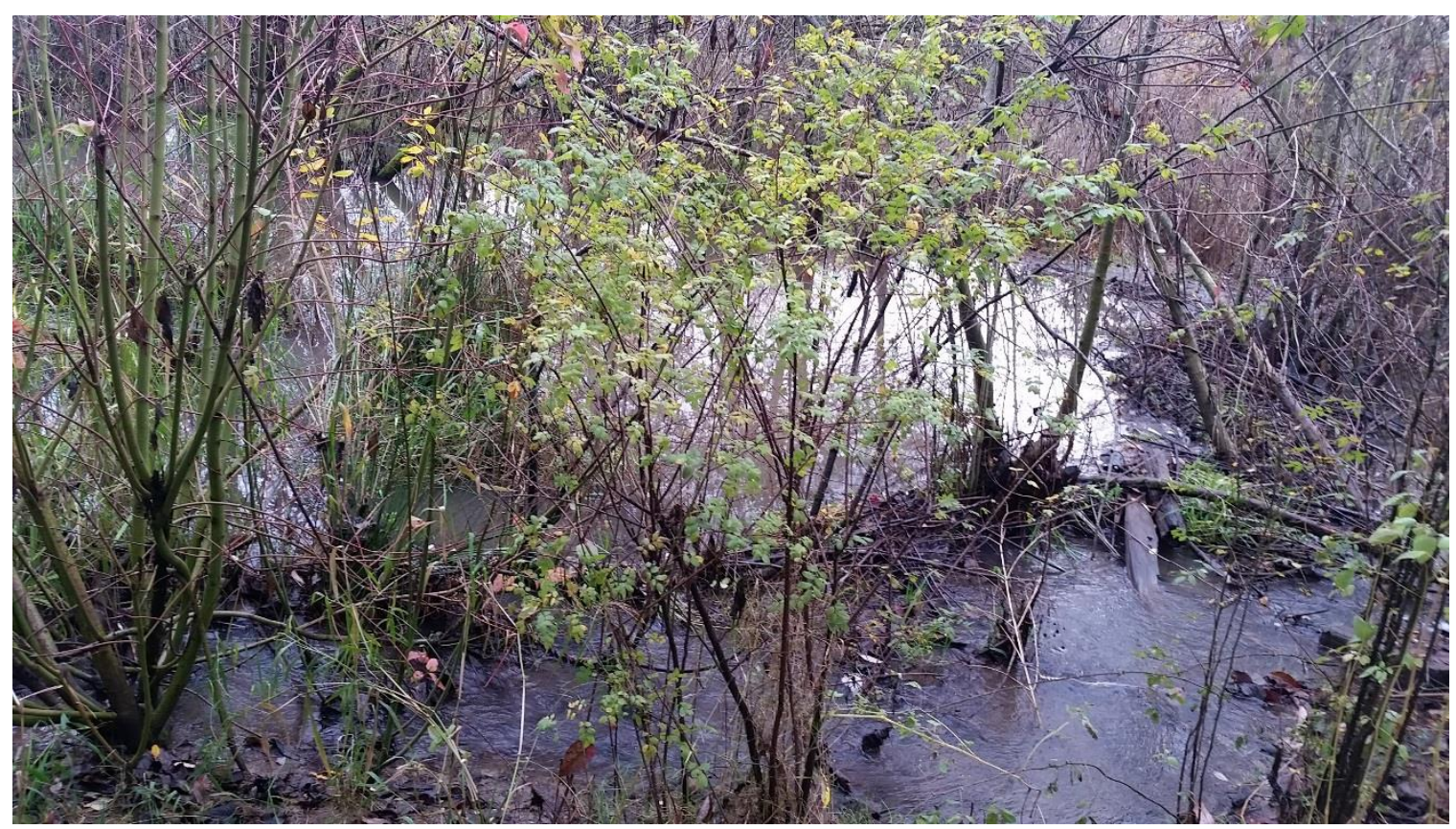

Figure 5. Dam 3 from right bank oriented to upstream left bank.

\section{Sample Collection}

Sediment samples were collected from twelve locations within the study site in January 2017 (Figure 2). Sample locations were selected that best represented the characteristics of the site. Locations were avoided where site conditions (ie. water depth at time of sampling, proximity to the non-visible channel) reduced accessibility and made sampling at these locations unsafe. Seven samples were collected from within the channel and five samples from the floodplain pond upstream of Dam 2 (Table 1), using a sludge sampler and extension poles. The sampler was extended to an undisturbed location and submerged until penetration was no longer possible (resistance met). The samples were extracted and description and coordinates of the sample locations were noted. Samples were stored in sealed quart sized bags at $5^{\circ} \mathrm{C}$ until processing. 
Table 1. Sediment Sample Identification and Location Table

\begin{tabular}{cll}
$\begin{array}{c}\text { Sample } \\
\text { Number }\end{array}$ & \multicolumn{1}{c}{ Location } & \multicolumn{1}{c}{ Profile } \\
\hline 1 & Non-impacted downstream of Dam 1 & channel \\
2 & Upstream of Dam 1 & channel \\
3 & Upstream of Dam 1 Mid-channel & channel \\
4 & Downstream of Dam 2 & channel \\
5 & Upstream of Dam 2 & floodplain \\
6 & Upstream of Dam 2 & floodplain \\
7 & Upstream of Dam 2 & floodplain \\
8 & Upstream of Dam 2 & floodplain \\
9 & Upstream of Dam 2 & floodplain \\
10 & Upstream of Dam 2 & channel \\
11 & Downstream of Dam 3 & channel \\
12 & Upstream of Dam 3 & \\
\hline
\end{tabular}

\section{Sample Processing}

Sediment samples were processed to determine percent organic matter and particle size composition. Since differently sized sediments can exhibit stratification upon deposition, samples were homogenized through hand mixing of sample bag contents. Three subsamples were selected from each sample bag using a 1 tablespoon scoop. ${ }^{1}$ All sample tins were individually weighed empty, filled with the subsample, and weighed again. Subsample weight was determined by subtracting the tin weight from the wet sample-tin combined weight. Samples were placed in a drying oven 12-24 hours at $120^{\circ} \mathrm{C}$. Once constant weight was achieved, each subsample was weighed and tin weight was subtracted from dry subsample weight for total dry weight.

To determine organic matter content, the dried samples were processed following Loss on Ignition procedures (NRCS 2014). This process consists of heating the samples to allow organic matter to "ignite", burning off the organic material and leaving only

\footnotetext{
${ }^{1}$ Only one sample was extracted from Sample 1 because the sample was too small for multiple subsamples.
} 
inorganic ash. The oven-dried subsamples were sifted through a $2 \mathrm{MM}$ sieve, and reweighed. Subsamples were placed in a muffle furnace heated to $425^{\circ} \mathrm{C}$ for 4 hours. After a cooling time of 20 minutes, subsamples were weighed and set aside. Once all individual subsamples were complete, subsamples were combined for total sample weight. Total sample organic matter was calculated by subtracting the post-ignition weight from the original dried weight.

Minerogenic particle size composition (percent sand/silt/clay) was determined following the micropipette procedure modified from Burt, Reinsch, and Miller (1993) (Lafrenz 2015). The purpose of this procedure is to calculate the particle size factions by separating clay and sand particles and determining faction weights. The twelve composite samples were ground with mortar and passed through a 2-millimeter sieve. Crucibles were weighed, filled with approximately 4 grams of each sample, and weighed again. The $4 \mathrm{~g}$ sample was transferred to a 50 milliliter $(\mathrm{mL})$ centrifuge tube and $10 \mathrm{~mL}$ of distilled water and 10mL of hexametaphosphate (HMP) solution were added to each tube, including one tube with only distilled water and HMP solution. The samples were horizontally shaken over night at low speed. Each sample was then filled with distilled water to achieve $40 \mathrm{ml}$ sample volume and allowed to cool for one hour. Individual samples were shaken for thirty seconds by hand and placed in a rack. At five minute intervals, the temperature was taken to determine the settling time for clay for each sample. At the approximate time a $2.5 \mathrm{~mL}$ sample was taken from each sample at a depth of $2.5 \mathrm{~cm}$, placed in a weighed tin, weighed again with sample contents, and oven dried overnight. The remaining centrifuge samples were each passed through a $0.052 \mathrm{~mm}$ sieve. The sand remaining on the sieve was placed in an evaporation dish, allowed to dry 
overnight at $110^{\circ} \mathrm{C}$, and weighed. Percent sand/silt/clay was then calculated based on the equations displayed in Figure 6.

$$
\begin{gathered}
\% \text { Clay }=\left(\frac{\text { Weight of Clay Sample }(g)-\text { Weight of HMP Solution }(g)}{\text { Total Weight of Oven }- \text { Dried Sample }(g)}\right) \times 100 \\
\% \text { Sand }=\left(\frac{\text { Weight of Sand Sample }(g)}{\text { Total Weight of Oven Dried Sample }(g)}\right) \times 100 \\
\% \text { Silt }=100-(\% \text { Clay }+\% \text { Sand })
\end{gathered}
$$

Figure 6. Equations used to calculate sediment particle sizes.

\section{Depth Surveys}

Sediment depth was determined based on survey data collected in conjunction with the U.S. Geological Survey (USGS) for site bathymetry and depth-to-resistance. Bathymetric elevations were defined as the elevation at the top of the surface of the deposited sediment layer (Figure 7). Depth-to-resistance was defined as elevation at which penetration through the deposited sediment layer was no longer possible (resistance met). In the summer of 2016, the USGS conducted a bathymetric survey of the study area main channel and pond upstream of Dam 2 using mechanical Total Stations and Real Time Kinematic (RTK) survey equipment. A partial depth-toresistance survey was conducted concurrently, and continued through fall 2016. In total, 394 bathymetric and 526 depth-to-resistance points were collected in the study area. To avoid gap and edge error during interpolation, in areas where data points were sparse near study area edges, elevation data from the 2014 LIDAR dataset was merged to the bathymetric and depth-to-resistance surveys. All survey point data were uploaded to ArcGIS 10.4.1 for interpolation. Dam 3 was not included in either survey. Depth data 
for the upstream and downstream locations were derived from the manual measurements and cross-validated with the channel improvement plan elevations and a 2014 LIDAR elevation model provided by Clean Water Services.

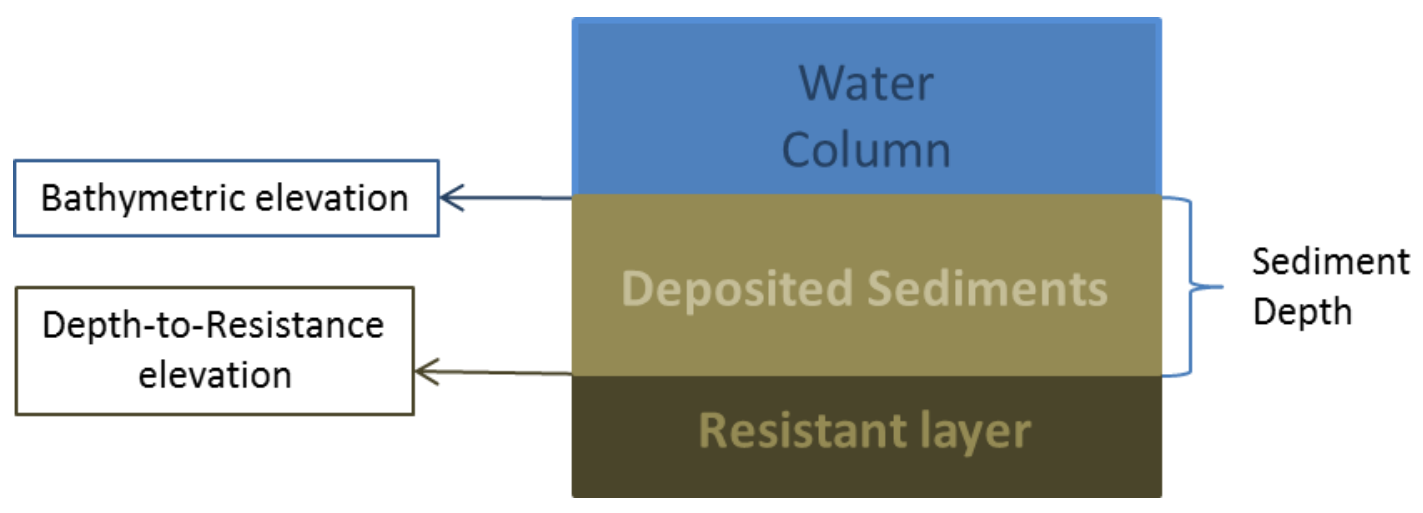

Figure 7. Diagram defining bathymetric and depth-to-resistance.

\section{Sediment Depth}

Bathymetric and depth-to-resistance survey points were interpolated to determine the depth of deposited sediment at sampling locations using ArcGIS 10.4.1 software. Spatial interpolation methods considered for the surveys were: Inverse Distance Weighted, Ordinary Kriging, Empirical Bayesian Kriging, Spline, and Topo to Raster. By conducting each interpolation method through the ArcGIS Geostatistical Analysist, model accuracy was assessed and the best fit model was accepted. The interpolated depth-to-resistance surface was subtracted from the bathymetric surface using GIS to develop a sediment depth continuous surface dataset. Sample location coordinates were uploaded into ArcGIS and the depth value extracted for each point.

Data Analysis

Both visual examination and descriptive statistics were performed to determine spatial variability of organic matter and particle size content and to identify relationships 
between depth and composition. ArcGIS was used to identify spatial variability of deposited organic matter and particle size distribution through a series of maps. Statistical software R Studio was used to calculate Spearman's Rho (rank-order) Coefficients $\left(r_{s}\right)$ and develop correlation plots between organic matter content, sediment composition, and the depth of the deposited layer. Spearman's Rho correlation was chosen for this analysis because the data in the study is not independent, normally distributed, nor does it exhibit linear relationships. Furthermore, Spearman's Rho is appropriate for small data sets that do not require the removal of outliers or address heteroscedasticity, and provides a stronger indicator of correlation between variables exhibiting monotonic relationships. Each variable was analyzed separately for in-channel samples versus floodplain samples, in-channel samples were assessed based upstream/downstream position in the dam system, and floodplain samples were assessed in relation to position in the pond. 


\section{$\underline{\text { Results }}$}

\section{Sample Composition}

All samples in this study were silt dominant ( $>88 \%$ ) (Table 2), which is consistent with the underlying basin geology. Organic matter content varied from 4.7 and 16.9 percent.

Table 2. Results of Sediment Sample Processing (floodplain samples in grey)

\begin{tabular}{rrrrr} 
ID & OM $(\boldsymbol{\%})$ & Sand $(\boldsymbol{\%})$ & Silt $(\boldsymbol{\%})$ & Clay $(\boldsymbol{\%})$ \\
\hline 1 & 9.0 & 0.1 & 91.7 & 8.2 \\
2 & 11.4 & 0.1 & 90.7 & 9.1 \\
3 & 4.7 & 0.3 & 92.4 & 7.3 \\
4 & 4.7 & 0.2 & 96.0 & 3.9 \\
5 & 7.8 & 0.5 & 88.4 & 11.1 \\
6 & 9.1 & 0.2 & 91.6 & 8.2 \\
7 & 11.5 & 0.1 & 92.5 & 7.4 \\
8 & 8.9 & 0.1 & 91.0 & 8.9 \\
9 & 14.5 & 0.1 & 92.5 & 7.5 \\
10 & 16.9 & 0.1 & 91.6 & 8.3 \\
11 & 7.5 & 0.3 & 94.3 & 5.5 \\
12 & 9.0 & 0.1 & 91.7 & 8.2 \\
\hline
\end{tabular}

\section{Sediment Depth}

Sediment depth interpolation resulted in gains and losses of sediment in the sample areas (Table 3). The interpolation method selected for the sediment and bathymetric surveys was Empirical Bayesian Kriging (EBK), which resulted in the best fit model for both surveys through error statistics and cross-validation using subset features (Appendix Table 1). Error values associated with each sample location were determined through GeoStatistical Analyst in ArcGIS and represent the variation between the interpolated value at the sample location and values of the surrounding cells. For example, Sample 1 has an interpolated depth value of $-0.69 \mathrm{~m}$, however the range 
associated with that measurement is $+/-0.37 \mathrm{~m}$. This range is a result of the uncertainty associated with interpolating continuous surfaces from discrete data points and indicates the variability of values collected.

Depths for upstream and downstream of Dam 3 were not generated through interpolation. Instead, they were calculated using manual measurements, thus the potential error was not calculated. There are a number of possible explanations for possible errors, including: interpolation error from irregular survey points or human survey collection errors.

Table 3. Sediment Depths Calculated from Interpolated

\begin{tabular}{rrr} 
Survey Surfaces (floodplain samples in grey) \\
\hline ID & Depth $(\mathbf{m})$ & Depth Error +/- (m) \\
\hline 1 & -0.69 & 0.37 \\
2 & 1.03 & 0.44 \\
3 & -0.90 & 0.41 \\
4 & -0.02 & 0.23 \\
5 & 0.96 & 0.40 \\
6 & 0.20 & 0.38 \\
7 & 0.23 & 0.05 \\
8 & 0.29 & 0.08 \\
9 & 0.26 & 0.15 \\
10 & 1.16 & 0.24 \\
11 & 0.37 & N/A \\
12 & 0.10 & N/A \\
\hline
\end{tabular}

Sediment depths vary differently for floodplain versus in-channel samples (Figure 8). Floodplain sediment depth decreases with distance downstream. In-channel sediment depths do not follow a distinct pattern. Dam 3 exhibited increased sediment depth downstream of the dam. Dams 1 and 2, however, has decreasing sediment depth downstream. Negative sediment depths were located within the constructed channel between Dams 1 and 2 and downstream of Dam 1. 


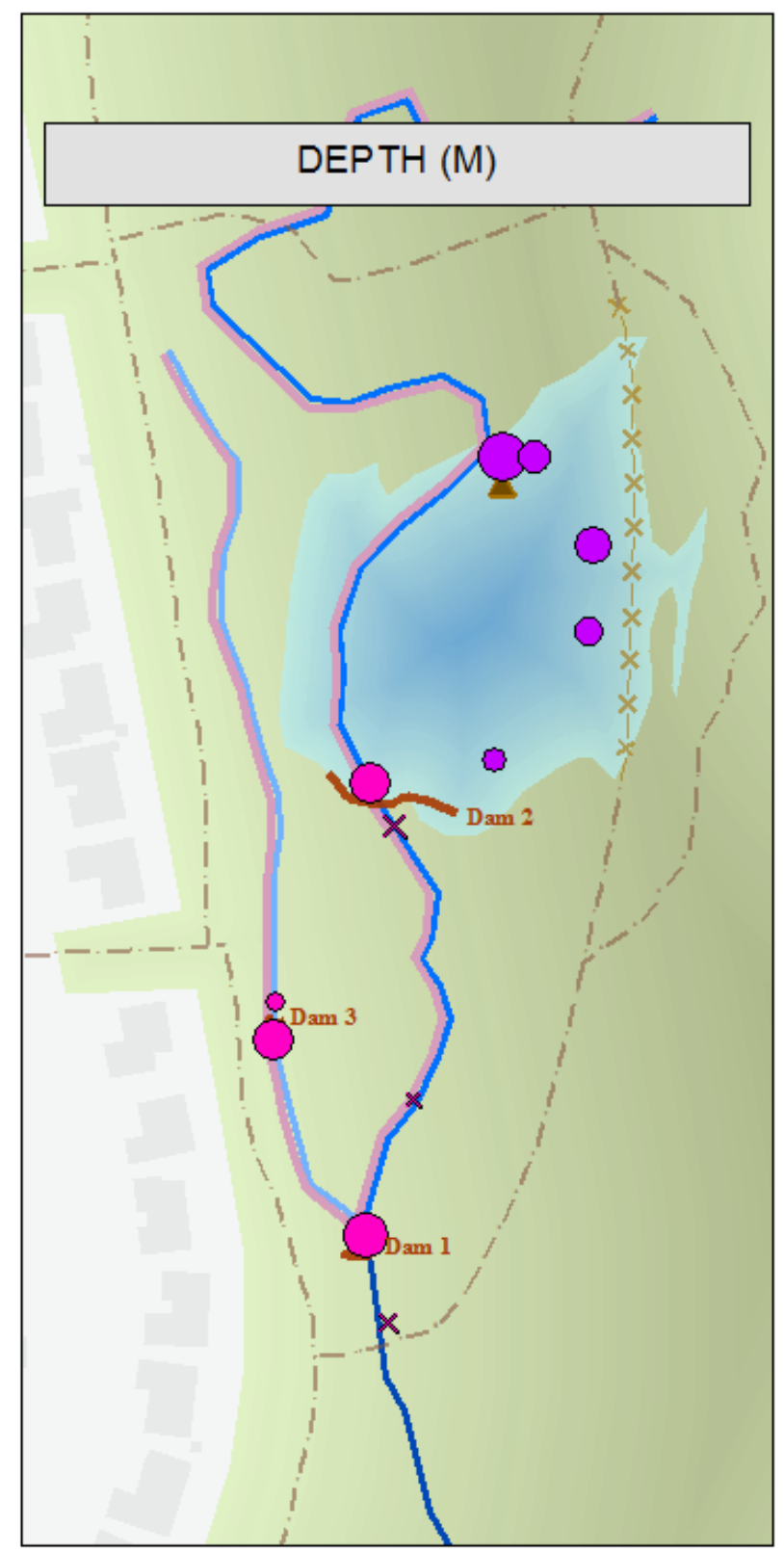

Figure 8 Map representing sediment depths using graduated symbols displaying relative changes in depth. Xs indicate negative depths.

\section{Data Analysis}

Sediment characteristics in the study area vary spatially and exhibit changes in percentage composition depending on position in the system: in-channel/floodplain, 
upstream/downstream of dam, and position in the floodplain. However, not all variables displayed clear patterns.

Organic matter content displayed clear spatial variability in the study area (Figure 8). A comparison of the mean percentages for in-channel $(7.7$, sd $=2.4)$ versus floodplain $(12.2, \mathrm{sd}=3.1)$ deposits indicates a larger amount of OM is being deposited in the floodplain than in the channel. However, floodplain deposits have a greater range of values (Figure 9). Organic matter varied between upstream and downstream in-channel samples (Figure 9 and Figure 10). Higher organic matter content was identified upstream of all dams in comparison to their downstream samples. Dam 1 had the highest organic matter content (11.4\%), followed by Dam $3(9.0 \%)$ and Dam 2 (7.8\%). Floodplain samples also displayed spatial variability in organic matter content. However, patters for floodplain samples are not as defined as upstream/downstream of dam samples. The highest percentages of organic matter are located in the upstream end of the ponded floodplain, samples 10 (14.5\%) and sample 11 (16.9\%). 

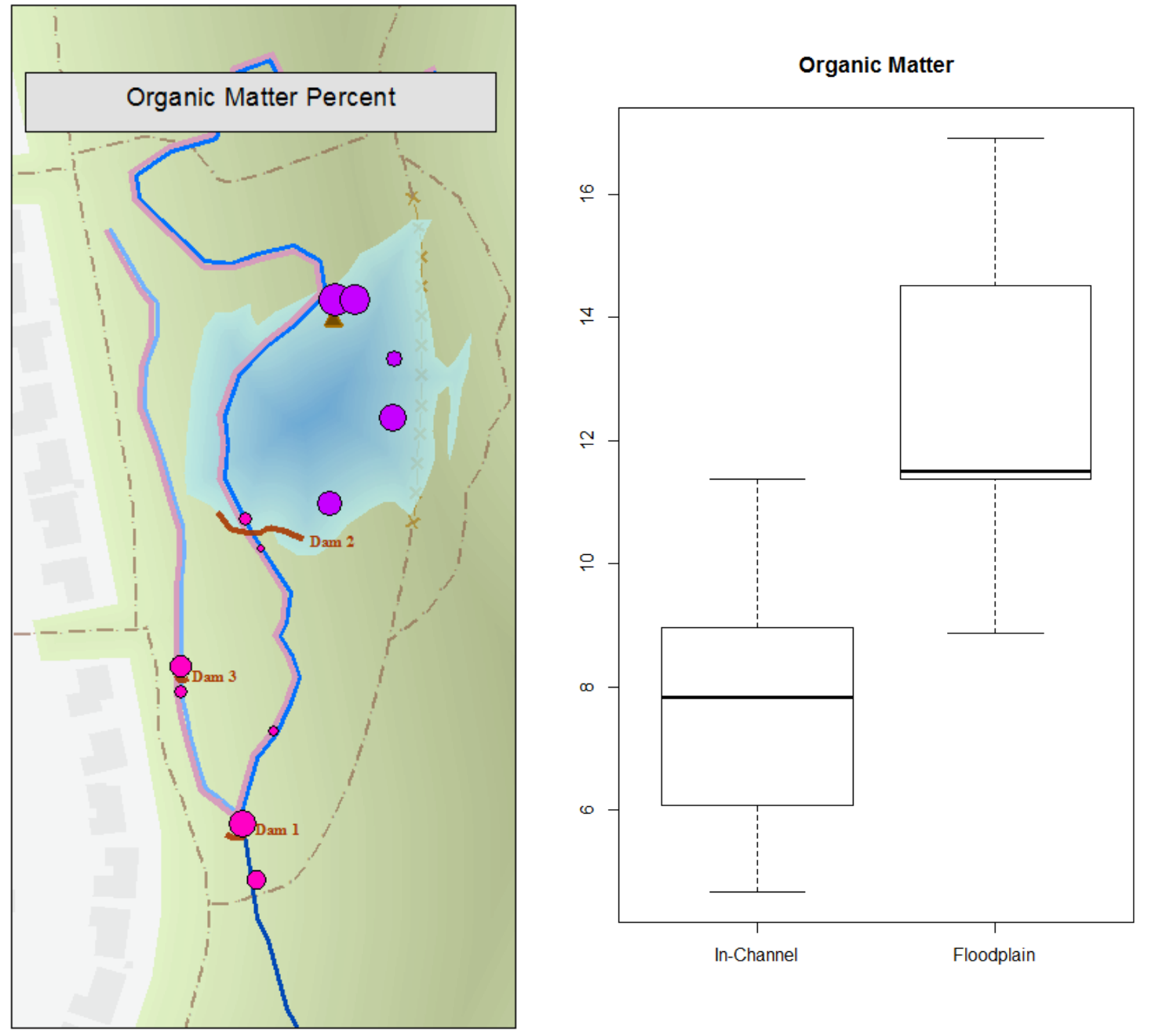

Figure 9. (Left) Map showing the spatial distribution of OM in collected samples using graduated symbols. (Right) Boxplot showing OM percentage in the floodplain pond is overall higher but with greater range of percentages in comparison to in-channel deposits. 

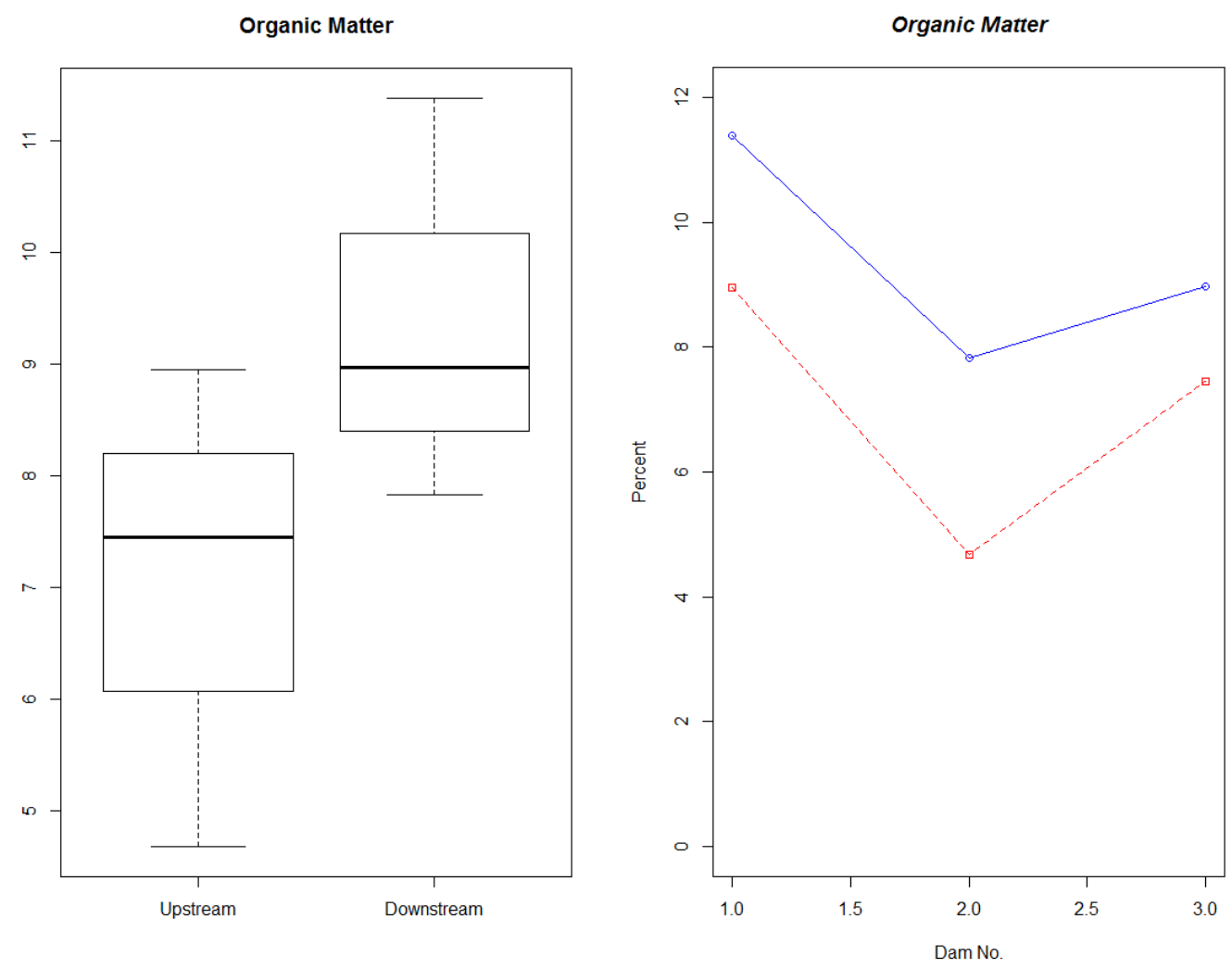

Figure 10. (Left) Boxplot of OM percentages upstream and downstream of the dams. (Right) Graphic of consistently higher OM upstream (blue) in comparison to downstream (red) for the individual dams (1,2, and 3).

All samples in this study were found to be silt dominant. However, particle sizes did exhibit spatial variability (Figure 11). In-channel sample averaged higher sand and silt sediments than floodplain samples (Table 2), while the floodplain samples contained a higher clay fraction than the in-channel samples. Upstream/downstream particle size composition patterns were consistent for all dams for silt and clay, with increasing percentages of silt downstream of the dams and decreasing percentages of clay downstream of the dam. Dams 1 and 2 had decreasing percentages of sand downstream of the dams. Inconsistent with Dams 1 and 2, Dam 3 contained increased sand downstream. Floodplain percent sand increased with distance downstream. However, floodplain silt and clay fractions did not display distinctive depositional patterns. 

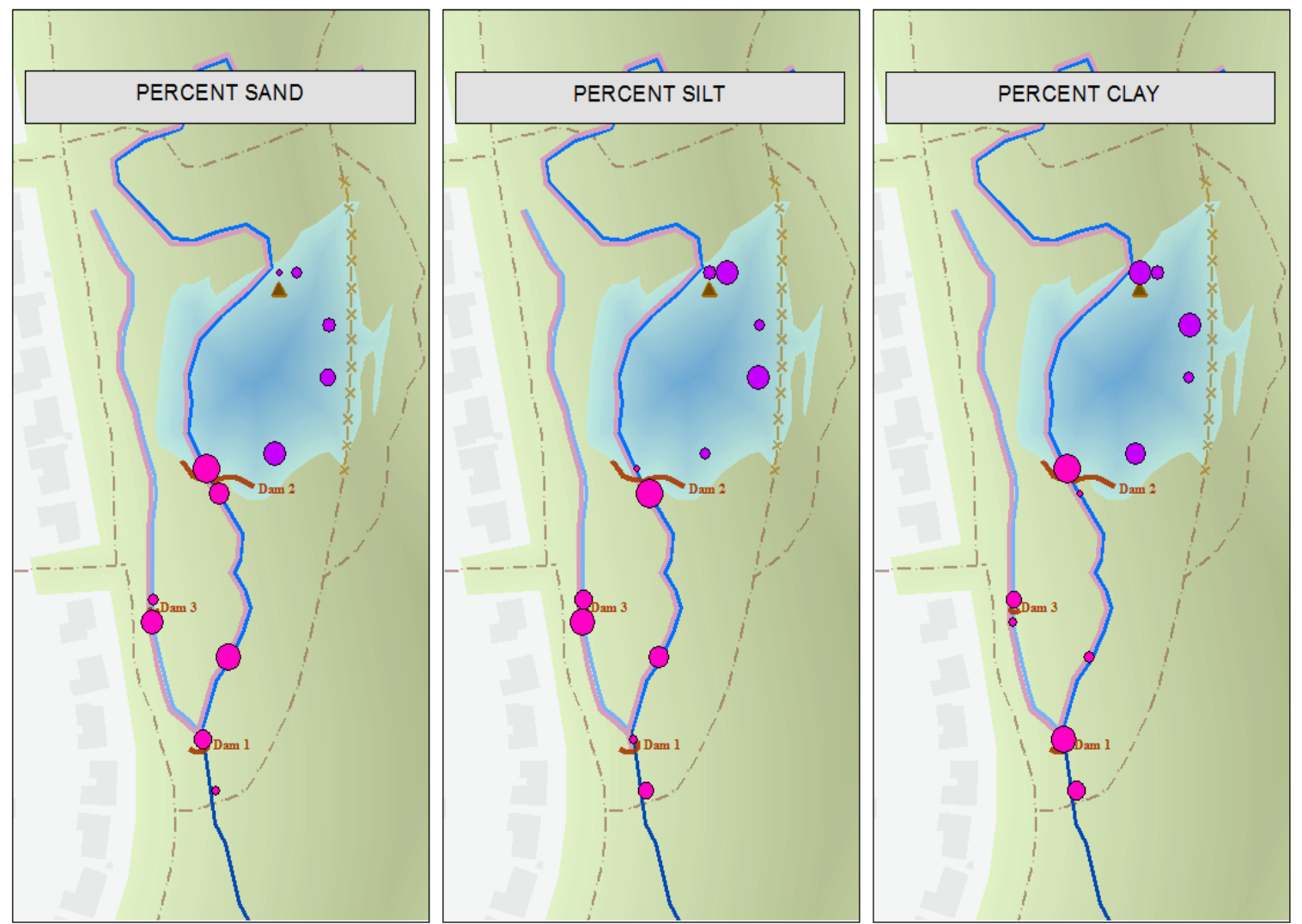

Figure 11. Percent sand (left), silt (center), and clay (right) for individual samples. Sand deposition in the floodplain displays the clearest dispositional pattern; however, in-channel patterns are not as clear.

Table 4. Mean Percentage of Particle Size by Location

\begin{tabular}{cccc}
\hline Location & $\begin{array}{c}\text { Sand } \\
(\boldsymbol{\%})\end{array}$ & Silt $(\boldsymbol{\%})$ & $\begin{array}{c}\text { Clay } \\
(\%)\end{array}$ \\
\hline In-Channel & 0.2 & 92.2 & 7.6 \\
Floodplain & 0.1 & 91.8 & 8.1 \\
\hline Upstream & 0.2 & 94.0 & 5.9 \\
Downstream & 0.3 & 90.3 & 9.5 \\
\hline
\end{tabular}

Moderate correlations between organic matter and depth of deposited sediments were produced in this analysis (Figure 12). Organic matter was more highly correlated to sediment depth for in-channel samples than floodplain samples. Both p-values indicate these correlations are not significant. Sample sizes were only large enough to analyze floodplain versus in-channel deposits (sample size > 5). 


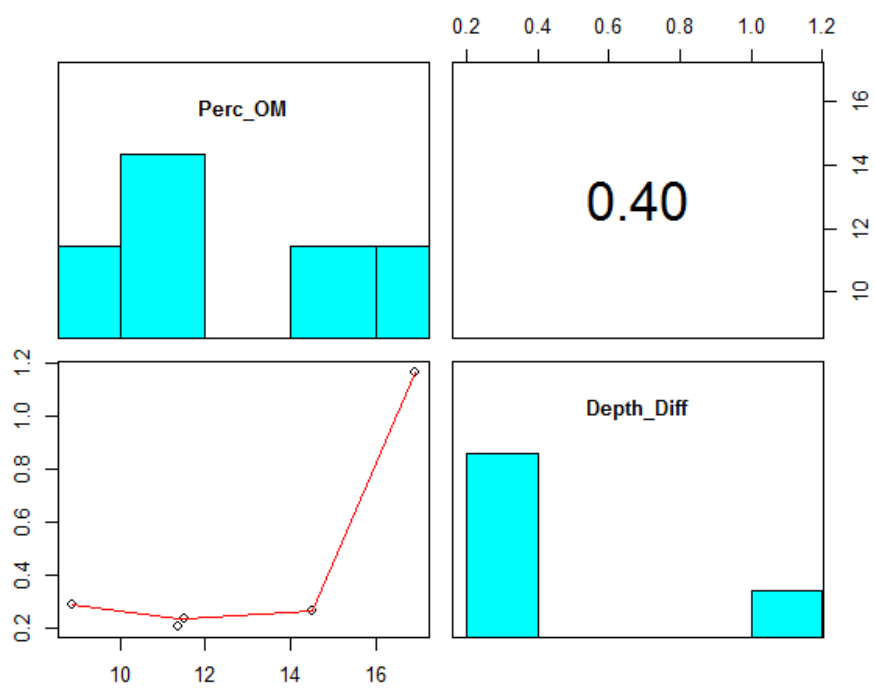

p-value $=0.26$

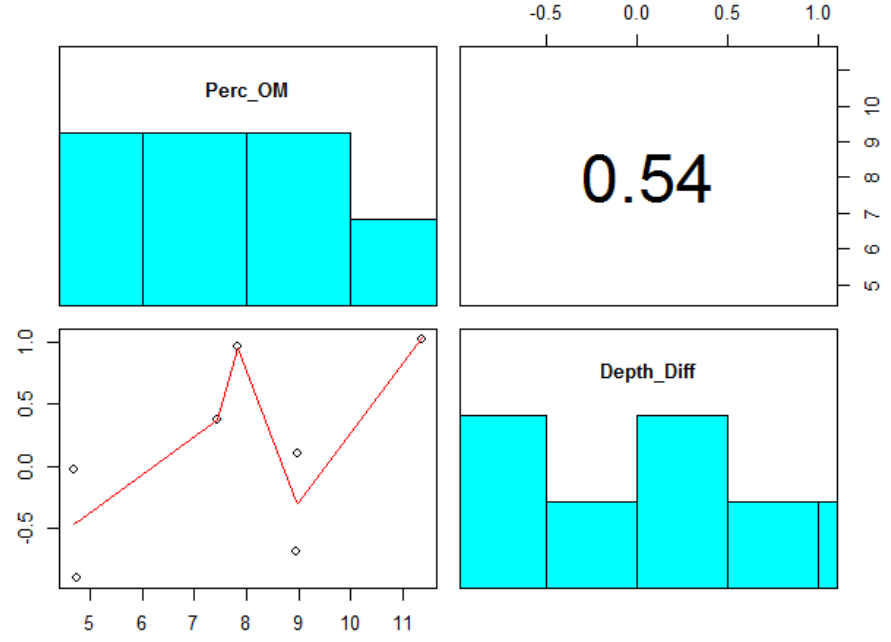

$\mathrm{p}$-value $=0.12$

Figure 12. Correlation matrices for floodplain (top) and in-channel (bottom) sediment samples. Spearman's Rho coefficients for both sample subsets do not differ significantly. P-values indicate the results are not significant (alpha $=0.05$ ).

Opposite correlations between organic matter and sediment particle size were identified for floodplain versus in-channel samples (Figure 13). For floodplain samples, the highest correlation coefficient was calculated between organic matter and percent sand, as sand increased organic matter degreased $\left(r_{s}=-0.70\right)$. There was moderate correlation between silt and clay percentages and organic matter, with coefficients of - 
0.50 and 0.05 respectively. In-channel samples produced higher coefficients for organic matter and silt (-0.71) and clay percentages (0.71). The relationship between organic matter and clay was the only relationship with a significant $\mathrm{p}$-value $(0.04$, alpha $=0.05)$. Organic matter and sand content resulted in a coefficient of -0.54 and lacked a clear increasing or decreasing relationship. 

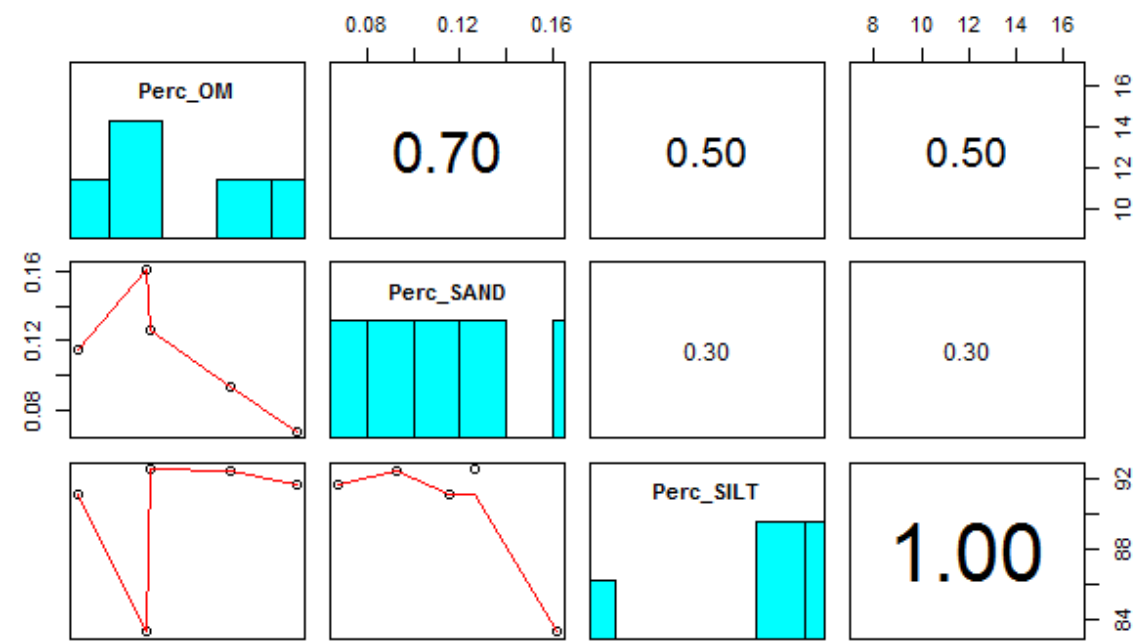

Sand p-value
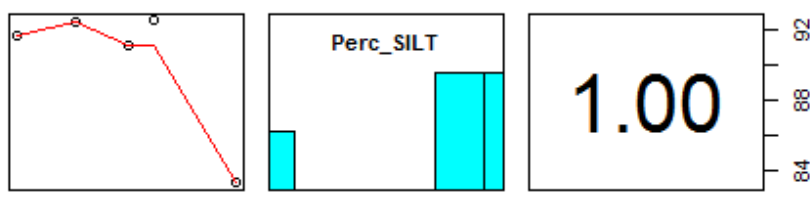

$=0.93$
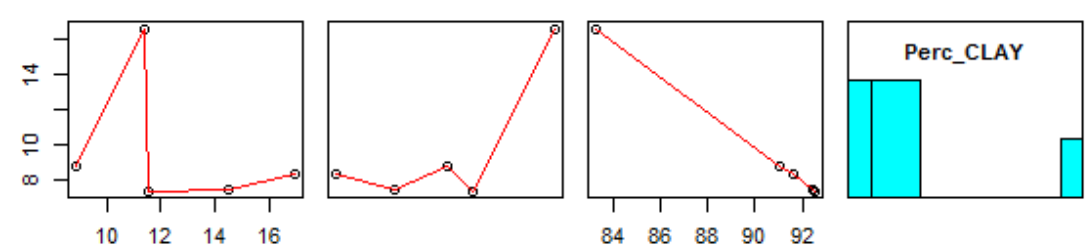

Silt p-value

$=0.23$

Clay p-value

$=0.83$
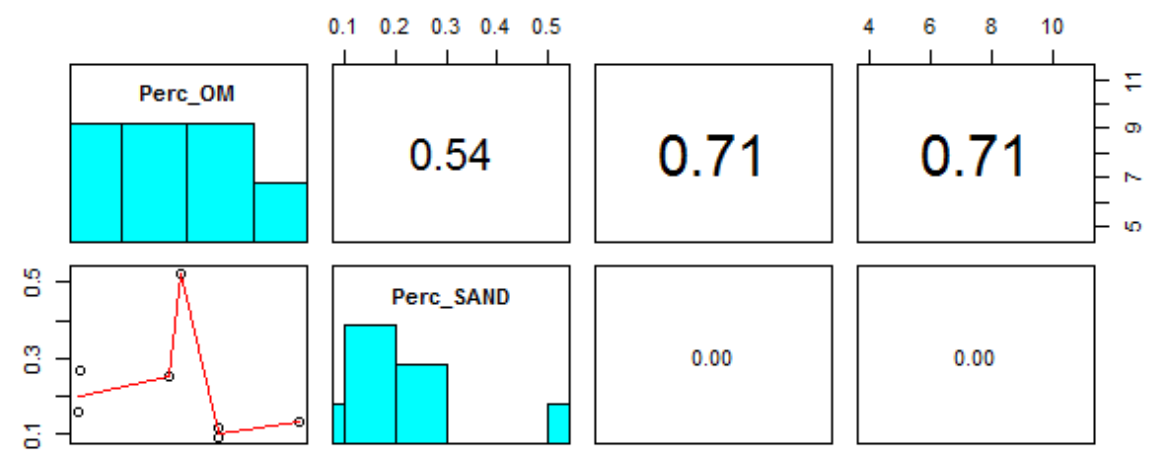

Sand p-value
$=0.90$
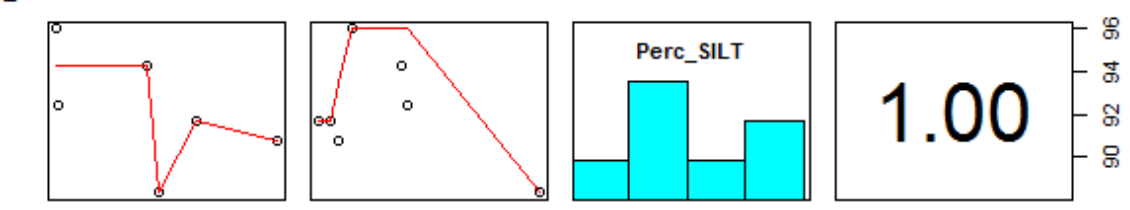

Silt p-value

$=0.97$
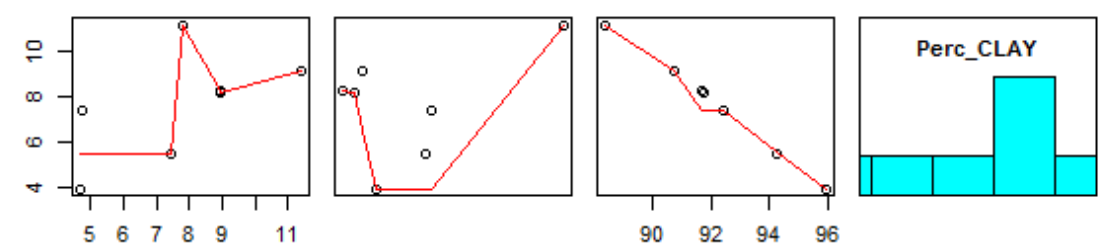

Figure 13. Correlation matrices for floodplain (top) and in-channel (bottom) sediment composition. The in-channel clay-organic matter relationship was the only relationship found to be statistically significant (alpha $=0.05$ ). 


\section{$\underline{\text { Discussion }}$}

The results of this research demonstrate that beaver activity has created different system components in the Fanno Creek study area. The presence of the dams created conditions favorable to trapping suspended sediment and particulates upstream of the dams. The reduction of discharge velocity slowed water and increased residence time of water, causing ponding in the channel and floodplain and allowed deposition to occur. This has initiated processes that can repair the incised condition of the channel (Pollack et al. 2014).

\section{Floodplain Sediments}

Beginning upstream in the dam system, the initial decrease in flow velocity occurs as the stream enters the ponded floodplain. When flow velocity falls below particle settling velocity, fine-grained particles fall out of suspension (Shields 1936). Sample 11 is the most upstream floodplain sample and indicates deposition is occurring heavily in this location (sediment depth $1.16 \mathrm{~m}$ ). Beyond Sample 11, floodplain sediment depths demonstrated moderate uniformity, ranging from 0.20 to $0.29 \mathrm{~m}$; however, depths decrease with distance downstream. Sample 6 had the shallowest sediment depth in the ponded area, likely because flow velocity in this location increases as a result of the redirection of flow from the channel across the left bank floodplain and around the dam. During storm flows, this avulsion velocity increases in this area and is likely high enough to re-suspend sediments and transport material downstream.

In contrast to sediment depth, sand content in the floodplain samples increased with distance downstream. This is likely attributed to a combination of in-channel flow velocities and particle density stratification. Flow velocities in the channel remain higher 
than overland flows as a result of greater surface roughness on the floodplain (Wyzga 1999). Suspended sand particles have been found to remain lower in the water column (Sahin et al. 2013), which reduces movement onto the floodplain and instead transports the main material along the channel. Upon deposition, sand particles maintain a higher entrainment threshold than silt and clay, only being transported when their critical threshold is achieved (Shields 1936, Dey 2011). This indicates that the sand faction of the suspended load in the study area was likely carried downstream by in-channel flow, settling behind Dam 2 or being transported over the lower floodplain and downstream. This also explains why Sample 6 has the highest floodplain sand content and why the floodplain samples contained the lowest percentage of sand overall $(0.12 \%)$.

Silt and clay percentages were inversely proportional for all floodplain samples, which could be a result of local beaver activity on sediment (Butler 1991) or changes in surface roughness (increased/decreased vegetation). The Spearman's Rho coefficients for particle size and organic matter indicate that as sand decreased (with corresponding increases in silt and clay), organic matter increased. Burone et al. similarly identified strong positive correlations between fine soil fractions and organic matter in Brazil (2003).

\section{In-Channel Sediments}

The initial effects of beaver dams occur in the channel, immediately upstream of a dam. Water and sediments are obstructed by dams built across the channel, causing changes in storage to occur in the channel directly upstream of the dam. The earliest

effects occur in the channel upstream of Dam 2, which trapped sediment to a depth of $0.96 \mathrm{~m}$ and contained the largest percentage of the sand particles $(0.53 \%)$. Immediately 
downstream of Dam 2, the channel depth interpolated negative values. Although these negative values could have resulted from data collection or interpolation error, it is also possible that erosion has occurred within the channel. The bathymetric survey and depthto-resistance surveys were not conducted at the same time and erosion from overbank flow could be responsible for bed losses. Headcut erosion is often found in beaver systems when redirected flow begins to carve a new channel (John and Klein 2004). As water elevations change between upstream and downstream of the dam and flow is redirected overland around the dam, the base of the channel downstream can erode. Eroded material is then carried downstream.

In-channel sample depths decrease downstream of Dam 2 until directly behind Dam 1 (sediment depth 1.03m). Sediment composition behind Dam 2 indicated that inchannel erosion may be taking place between Dams 1 and 2. As mentioned in the description of the study area, the constructed channel consists of clay bank material. The clay content of Sample 2 is greater than $9 \%$; this is surpassed only by the clay content behind Dam 2 (11.12\%), which may also be experiencing bank failures within the ponded area.

In contrast to Dams 1 and 2, Dam 3 exhibited higher sediment depth at the downstream sample site. The position of Dam 3 may produce processes unique to the site. Dam 3 is located in the old channel that was filled with excavated material from the constructed channel. As the downstream sample location at Dam 3 experiences ponding from Dam 1, the filled material may remain only loosely consolidated which may be allowing bed material to be collected as part of the sample. Additionally, Dam 3 is an overtopping dam experiencing constant variable flow subject to both local stormwater 
and stream system inputs. As a stormwater inlet, Dam 3 received direct input during storm events, but also receives overland inputs from the stream when water levels upstream of Dam 2 are high enough to connect the constructed and old channels. At times ponding has been high enough to completely inundate the land area between Dams 2 and 3 , resulting in the connection of the entire old channel and the creation of a singular system spanning pond upstream of Dam 1. This combination of factors results in two distinct reactions: slow flow-stagnant and rapid-rising inputs from multiple sources creating complex deposition-flush-erosion-deposition dynamics not experienced by the other dams and could potentially explain some of the inconsistencies Dam 3 exhibits with the other sites.

Similar to the floodplain samples, in-channel samples showed a decrease in sand content with distance downstream. This is in contrast to the findings of De Visscher et al., who found a coarsening of sediments downstream; however the authors attributed these results to the flush of sediments occurring after a breach (2013). The coarseness of the samples upstream in this study suggests stable dams and a lack of dam failures. Sand content was higher upstream of Dams 1 and 2. John and Klein found increases in sand deposition at the back of ponded areas aid in the creation of mouth bars (2004). As Fanno Creek is a very low gradient slow moving stream and the channel reach between Dams 1 and 2 is an excavated clay channel, the possible creation of a sand bar is another example of how beaver can alter channel morphology. However, a more comprehensive survey and sampling regime is needed to confirm the presence and creation of in-channel structures. 
The silt and clay content of in-channel samples exhibited the same inverse relationship as floodplain samples. In-channel clay content was higher upstream of Dams 1 and 2, while silt content was higher downstream of Dams 1 and 2. There are number of factoring influencing the storage or transport of clay particles. Similar to the stratification of sand particles in the water column, clay particles can be stratified in the water column because of clumping (Sahin et al. 2013). Cohesive clay clump mass can cause clay particles to settle faster under low flow velocities, while lighter loose clay particles will continue to remain in suspension. As both Dams 1 and 2 experience continuous flow through channel avulsions, this flow will continue to transport loose suspended clay particles out of the system. Particles of suspended silt have a higher fall threshold than loose clay particles. As a result silt particles dominate downstream deposited sediments and suspended clay is carried out of the beaver dam system.

High silt and clay content corresponds to high organic matter content of inchannel samples; this is expected as organic matter readily binds with clay particles (Schnitzer 1986). Organic matter and silt/clay relationships show opposite correlations, with organic matter increasing with increasing clay and decreasing with increasing silt. Additionally, organic matter content was higher at Dams 1 and 3, which are surrounded by more riparian vegetation than Dam 2. These riparian areas input organic matter (ie. leaf litter) directly into the stream, while vegetation surrounding Dam 2 has been subject to floodplain ponding and die-off and does not produce the same input. The ponding at Dam 2 also creates an idyllic environment for increased decomposition of organic matter settled into the system. The ponding upstream of Dam 2 increases water surface area and reduces shading, this allows for increased reception of solar radiation and causes water 
temperatures to increase in areas of shallow ponding (ie. behind the dam and on the floodplain). Increased temperatures can spur the decomposition of organic matter and reduce overall organic matter storage (Contant et al. 2011).

\section{Limitations of this Study}

To better understand the dynamics of urban beaver systems, it is important to understand and discuss the limitations of this research. This project's limitations included: irregular point elevations surveys and the errors associated with the subsequent interpolated surfaces, temporal variability of data collection tasks, and limited sample sizes.

Acknowledging the difficulty of collecting elevation data in a turbid, incised, nonwadeable stream with complex vegetation patterns, future studies should give special consideration to the collection of point data, although it can be difficult to identify ideal conditions that minimize the disruption of satellite signals by canopy cover, while maintaining safe working conditions (ie. low/non-event flow conditions). Additionally, surface interpolation method should be predetermined to assist in the development of a data collection plan.

Although many interpolation methods were considered in the process of this research, non-interpolation methods were not considered. De Visscher et al. addressed the limitations of interpolating continuous surfaces with boundaries and chose to calculate sediment depths using Theissen polygons (2014). A comparison of interpolation versus polygon determination of sediment depth was not considered in this analysis. 
Some of conclusions suggested in this study are supported by literature and geomorphic theory and yet, count not be definitively tested. For example, erosive headcut processes causing negative sediment values are not conclusive; however, had the bathymetric and depth-to-resistance surveys been conducted concurrently, a follow-up study might be able to provide conclusive evidence of bed losses.

Project objectives, methods, and expected results should be clearly defined in the development of future projects. Although randomness and complications are expected in field studies of this kind, this project would have benefited from additional planning and study development prior to execution. 


\section{$\underline{\text { Conclusion }}$}

Sedimentation patterns in the Fanno Creek beaver system in Greenway Park exhibits many of the same processes and forms identified in natural (non-urban) beaver systems. In Fanno Creek, which experiences abundant suspended particle load, the beaver system acts as a sink for sediment and organic matter. The composition of sediments in the study area displayed spatial variability. The mechanisms underlying this variability were not addressed this this study; correlative relationships were difficult to identify because of the limited sample size, but could be more clarified with a more robust dataset.

The beaver system engineered in the study reach has reconnected the incised stream with the adjacent floodplain. The floodplain and stream bed have experienced gains in elevation upstream of the dams as a result of the increase in storage. Samples in the Fanno Creek study area indicate sediments of both local and external upstream sources, providing enough sediment to cause channel structure evolution. In time, deposited sediment and organic matter will create a rich environment conducive to the establishment by vegetation, trapping additional sediment and reducing erosion.

The problems of erosion and sediment supply in Fanno Creek are commonly experienced by streams in urban basins. If left to continue its current trajectory, Fanno Creek is likely to experience a channel evolution few urbanized streams undergo. This study area provides a unique opportunity to develop an understanding of how ecology, hydrology, and geomorphology respond to the stressors induced by impervious surfaces in a stream basin and giving land managers an opportunity to explore and capitalize on the environmental and social benefits of combining human built and natural systems. 


\section{$\underline{\text { References }}$}

Clean Water Services (CWS) and Resource Consultants, Inc. 2009. Fanno Creek Greenway Park Channel Improvements. Personal communication 2016.

Burchsted, D., Daniels, M., Thorson, R., and Vokoun, J. 2010. The River Discontinuum: Applying Beaver Modifications to Baseline Conditions for Restoration of Forested Headwaters. BioScience 60:908-922

Burone, L., Muniz, P., Pires-Vanin, A.M., Rodrigues, M.. 2003. Spatial distribution of organic matter in the surface sediments of Ubatuba Bay (Southeastern-Brazil). Annals of the Brazilian Academy of Sciences. 75(1):77-90

Burt, R., Reinsch, T.G., and Miller, W.P. 1993. A micro-pipette method for water dispersible clay. Commun. Soil Sci. Plant Anal. 24:2531-2544. (\#318)

Butler, D.R. 1991. Beavers as agents of biogeomorphic change: a review and suggestions for teaching exercises. Journal of Geography 90(5):210-217

Champ, D. R., Gulens, J., and Jackson, R. E. 1979. Oxidation-reduction sequences in groundwater flow systems. Canadian Journal of Earth Sciences 16: 12-23

Charlton, R. 2008. Fundamentals of Fluvial Geomorphology. Abingdon, Oxon, England: Routledge.

Contant, R. T., Ryan, M.G., Agren, G. I., Birge, H. E., Davidson, E. A., Eliasson, P. E., Evans, S. E., Frey S. D., Giardina, C. P., Hopkins, F. M., Hyvonen, R., Kirschbau, M. U. F., Lavallee, J. M., Leifeld, J., Parton, W. J., Steinweg, J. M., Wallenstein, M. D., Wetterstedt, M. J. A., Bradford, M. A. 2011. Temperature and soil organic matter decomposition rates- synthesis of current knowledge and a way forward. Global Change Biology. 17:3392-3404

De Visscher, M., Nyssen, J., Pontzeele, J., Billi, P., and Frankl, A. 2013. Spatio-temporal sedimentation patterns in beaver ponds along the Chevral river, Ardennes, Belgium. Hydrological Processes. 28(4): 1602-1615

Dey, S. 2011. Entrainment Threshold of Loose Boundary Streams. Experimental Methods in Hydraulic Research. Experimental methods in hydraulic research, geoplanet:Kirsch Earth and planetary sciences, P.Rowinski, ed., Springer, Berlin.

Devito, K. J. and Dillon, P. J. 1993. The influence of hydrologic conditions and peat oxia on the phosphorus and nitrogen dynamics of a conifer swamp. Water Resources Research. 29(8): 2675-2685

Gerhardt, A. 1992. Effects of subacute doses of iron (Fe) on Leptophlebia marginata (Insecta: Ephemeroptera). Freshwater Biology 27: 79-84

Graham, A. A. 1990. Siltation of stone-surface periphyton in rivers by clay-sized particles from low concentrations in suspension. Hydrobiologia. 199(2): 107-115 
Groffman, P. M., Bain, D. J., Band, L. E., Belt, K. T., Brush, G. S., Grove, J. M., Pouyat, R. V., Yesilonis, I. C., Zipperer. W. C. 2003. Down by the riverside: Urban Riparian ecology. Frontiers in Ecology and the Environment. 1: 315-321

Grunell, A. M. 1998. The hydrogeomophological effects of beaver dam-building activity. Progress in Physical Geography. 22(2): 167-189

O’Driscoll, M., Clinton, S., Jefferson, A., Manda, A. and McMillan, S. 2010.

Urbanization Effects on Watershed Hydrology and In-Stream Processes in the Southern United States. Water 2: 605-648

John, S. and Klein, A. 2004. Hydrogeomorphic effects of beaver dams on floodplain morphology: avulsion processes and sediment fluxes in upland valley floods (Spessart, Germany). Quaternaire 15:219-231

Jones C. G., Lawton, J. H., and Shachak, M. 1994. Organisms as ecosystem engineers. Oikos 69: 373-386

Karickhoff, S. W., D. S. Brown, T. A. Scott. 1979. Sorption of hydrophobic pollutants on natural sediments. Water Research 13(3): 241-248

Keith, M. K., Sobieszczyk, S., Goldman, J. H., and Rounds, S. A. 2014. Investigating organic matter in Fanno Creek, Oregon, Part 2 of 3: Sources, sinks, and transport of organic matter with fine sediments. Journal of Hydrology. 519: 3010-3027

Keller, E.A. and Swanson, F. J. 1979. Effects of large organic debris on channel form and fluvial process. Earth Surface Processes 4: 361-80.

Lafrenz, M. D. 2015. Modified Micro-Pipette Method for Particle Size Analysis. Personal communication. Portland State University Geography Department Soil Lab

Lemly, A. D. 1982. Modification of benthic insect communities in polluted streams: combined effects of sedimentation and nutrient enrichment. Hydrobiologia. 87(3): 229245

Naiman, R. J., Johnston, C. A. and Kelley, J. C. 1988. Alteration of North American streams by beaver. Bioscience 38, 753-62.

Naiman, R. J., Melillo, J. M., and Hobbie, J. E. 1986. Ecosystem alteration of boreal forest streams by beaver (Castor canadensis). Ecology 67, 1254-69.

Natural Resources Conservation Service (NRCS). 2012. Soil Survey Geographic (SSURGO) Database for various counties, Oregon. Prepared by Soil Survey Staff, Natural Resources Conservation Service, U.S. Department of Agriculture. Accessed January 30, 2017 from https://www.nrcs.usda.gov/Internet/FSE_MANUSCRIPTS/oregon/OR067/0/or067_text.p df

Natural Resource Conservation Service Soil Survey Field and Laboratory Methods Manual. 2014. Soil Survey Investigations Report No. 51 Version 2. United States Department of Agriculture Natural Resources Conservation Service. Accessed January 
30, 2017 from

https://www.nrcs.usda.gov/Internet/FSE_DOCUMENTS/stelprdb1244466.pdf.

Paine R.T 1969. A note on trophic complexity and community stability. The American Naturalist 103:91-93

Paul, M. J., and Meyer, J. L. 2001. Streams in the Urban Landscape. Annual Review of Ecology and Systematics, 32(1), 333-365.

Pollock, M. M., Heim, M., and Werner, D. 2003. Hydrologic and Geomorphic Effects of Beaver Dams and Their Influence on Fishes. National Oceanic and Atmospheric Administration, Northwest Fisheries Science Center, 2725 Montlake Boulevard E., Seattle, Washington 98112, USA

Pollock, M. M., Beechie, T. J., and Jordan, C. E. 2007. Geomorphic changes upstream of beaver dams in Bridge Creek, an incised stream channel in the interior Columbia River basin, eastern Oregon. Earth Surface Processes and Landforms 32: 1174-1185

Pollock, M. M., Beechie, T. J., Wheaton, J. M., Joseph, M., Jordan, C. E., Bouwes, N. Weber, N. and Volk, C. 2014. Using Beaver Dams to Restore Incised Stream Ecosystems. BioScience 64(4), 279-290.

Pollock, M., Jordan, C., Lewallen, G., Woodruff, K., and Castro, J. 2015. The Beaver Restoration Guidebook Version 1.0. US Fish and Wildlife Agency Report.

Sahin, C., Safak, I., Hsu, T. and Sheremet, A. 2013. Observations of suspended sediment stratification from acoustic backscatter in muddy environments. Maine Geology. 336: 2432

Schnitzer M. 1986. Binding of humic substances by soil mineral colloids. Interactions of Soil Minerals with Natural Organics and Microbes. P.M. Huang \& M. Schnitzel editors Soil Sci. Soc. America, Wisconsin. Pp. 83-87

Shields, A.F. 1936. Application of similarity principles and turbulence research to bedload movement, vol 26. Mitteilungen der Preussischen Versuchsanstalt f€ur Wasserbau und Schiffbau,Berlin, Germany, pp 5-24

Sullivan, K., Lisle, T. E., Dolloff, C. A., Grant, G. E., and Reid, L. M. 1987. Stream channels: the link between forests and fishes. In Salo, E.O. and Cundy, T.W., editors, Streamside management: forestry and fishery interactions, proceedings of a symposium, 12-14 February 1986, Seattle, Washington, College of Forest Resources, University of Washington, 39-97.

U. S. Environmental Protection Agency (EPA). 1992. Sediment classification methods compendium. EPA-823-R-92-006.

Violin, C. R., Cada, P., Sudduth, E. B., Hassett, B. A., Penrose, D. L., and Bernhardt, E. S. 2011. Effects of urbanization on urban stream restoration on the physical and biological structure of stream ecosystems. Ecological Applications 21(6): 1932-1949 
Walsh, C. J., Roy, A. H., Feminella, J. W., Cottingham, P. D., Groffman, P. M.and Morgan, R. P. II. 2005. The urban stream syndrome: Current knowledge and the search for a cure. Journal of the North American Benthological Society 24 (3): 706-23.

Wang, H., Hondzo, M., Xu, C., Poole, V., and Spacie, A. (2003). Dissolved oxygen dynamics of streams draining an urbanized and an agricultural catchment. Ecological Modelling, (160), 145-161.

White, D.S. 1990. Biological relationships to convective flow patterns within stream beds. Hydrobiologia 196: 149-58.

Wood, P. J. and Armitage, P. D. 1997. Biological Effects of Fine Sediment in the Lotic Environment. Environmental Management 21(2): 203-217

Wyzga, B. 1999. Estimating mean flow velocity in channel and floodplain areas and its use for explaining the pattern of overbank deposition and floodplain retention.

Geomorphology. 28: 281-297 
$\underline{\text { Appendix }}$

Table 1. Interpolation Error for EBK Interpolated Surfaces.

\begin{tabular}{lccr} 
Survey & $\begin{array}{c}\text { Root Mean } \\
\text { Square } \\
\text { Error }\end{array}$ & $\begin{array}{c}\text { Average } \\
\text { Standard } \\
\text { Error }\end{array}$ & $\begin{array}{c}\text { Root Mean } \\
\text { Square } \\
\text { Standardized }\end{array}$ \\
\hline Bathymetric & 0.27 & 0.27 & 0.96 \\
Depth-to-Resistance & 0.26 & 0.34 & 0.85 \\
\hline
\end{tabular}

